\title{
MAŁGORZATA FILIPEK
}

Uniwersytet Wrocławski, Polska

\section{Hiszpania w Dziennikach z podróży Miodraga Popovicia}

Zwiedzanie obcych krajów i poznawanie innych kultur wiąże się z odbywaniem podróży, które są jedną z podstawowych aktywności człowieka. We współczesnym świecie środki masowego przekazu tak bardzo upowszechniły doświadczenie podróży, że stało się ono integralną częścią praktyk społecznych i kulturowych. „Stan żeglowania [...] po oceanie obcego kontekstu kulturowego [...] zdaje się być obecnie kondycją permanentną"1. Literatura ukazująca obce przestrzenie obejmuje zarówno relacje o charakterze dokumentarnym, jak i narracje o podróżach zmyślonych, skonstruowanych czasami z pominięciem wzorca realistycznego ${ }^{2}$. Wprawdzie podróż realna może okazać się doświadczeniem uboższym intelektualnie i duchowo niż podróż wyobrażona, jednak tylko rzeczywista wyprawa umożliwia kontakt $\mathrm{z}$ innym światem nawet wtedy, gdy kontakt ten jest jedynie powierzchowny i wybiórczy ${ }^{3}$.

Piśmiennictwo od czasów Homera i Hezjoda, poprzez Gilgamesza i Stary Testament, do Tory i Koranu poświęcone jest Innym ${ }^{4}$. Pisarstwu antycznemu znane były głównie formy podróży użytkowej; piśmiennictwo greckie znamionowały sprawozdania i przewodniki krajoznawcze — „periegezy”, zawierające charakterystyki miejscowości zaznaczonych na mapie wraz z ich zabytkami oraz radami dla wyruszających w drogę. Rzymskie „itineraria” także mają charakter przewodnika lub opisu etnograficzno-geograficznego ${ }^{5}$. W pisarstwie średniowiecznym, podporządkowanym głównie celom religijnym, znaczącą rolę odgrywały

${ }^{1}$ W.J. Burszta, Różnorodność i tożsamość. Antropologia jako kulturowa refleksyjność, Poznań 2004, s. 88.

2 Słownik terminów literackich, red. M. Głowiński et al., Wrocław 2000, s. 394.

${ }^{3}$ K. Podemski, Socjologia podróży, Poznań 2004, s. 12.

${ }^{4}$ R. Kapuściński, Ten Inny, Kraków 2006, s. 11.

5 O. Płaszczewska, Wizja Włoch w polskiej i francuskiej literaturze okresu romantyzmu (18001850), Kraków 2003, s. 33. 
relacje z pielgrzymek, w których rzeczowy przekaz uzupełnia fantazja odautorska $^{6}$. W epoce renesansu, obok relacji z nowo odkrytych terytoriów ${ }^{7}$, sprawozdań z podróży dyplomatycznych i handlowych, zrodziła się konwencja podróży utopijnej, zapoczątkowana przez Tomasza Morusa (1478-1535). W XVIII w. popularność zyskały wyprawy intelektualne, wypełnione refleksjami o życiu społecznym i obyczajach mieszkańców odwiedzanych terytoriów. Owocem podróży stały się dzienniki, wspomnienia, pamiętniki, przeróżne odmiany opisów i powieści podróżniczych, w których przeżycia mieszały się z fantazją podróżników ${ }^{8}$. Z kolei w epoce romantyzmu zwiedzanie nie wymagało już pełnej dystansu postawy obiektywnego obserwatora, a spojrzenie zabarwione emocjonalnie, mieszające wrażenie z marzeniem, otwierało drogi ucieczki od rzeczywistości ${ }^{9}$.

W literaturze serbskiej elementy opisu podróży pojawiły się już w średniowiecznych utworach biograficznych, a najpopularniejszy gatunek podróżniczy aż do XVIII w. stanowiły relacje $\mathrm{z}$ wędrówek do miejsc kultu religijnego ${ }^{10}$, ukazujące podróż jako wyprawę w celu wypełnienia misji chrześcijańskiej ${ }^{11}$. Podróż jako aktywność służąca zdobywaniu wiedzy i poznawaniu nowych przestrzeni zaczęła nabierać znaczenia, podobnie jak w innych literaturach europejskich, w epoce oświecenia $^{12}$. W XIX stuleciu w relacje z podróży obfitowały utwory o charakterze autobiograficznym ${ }^{13}$. Za najlepszego autora prozy podróżniczej uważany

6 Ibidem.

7 H.O. Prens, H.M. Golobof, Istorija hispanoameričke književnosti, sa španskog prevela M. Josimčević, Beograd 1982, s. 7.

8 O. Płaszczewska, op. cit., s. 34.

9 A. Wieczorkiewicz, Apetyt turysty. O doświadczaniu świata w podróży, Kraków 2008, s. 104.

10 С. Јаћимовић, Путописи српске авангарде, Београд 2005, s. 9. Utworami o takim charakterze są: Żywot świętego Sawy (Житије светог Саве) autorstwa mnicha Domentijana (ok. 1210-po 1264), opisujący wyprawę Rastka Nemanjicia (ok. 1174-1236); Żywot św. Sawy, napisany przez mnicha Teodosija (XIII/XIV w.) oraz relacje z pielgrzymek do Jerozolimy (Onисаније Јерусалима, 1662) Gavrila Tadicia (ok. 1640-po 1715). Zainteresowanie samym faktem podróżowania charakteryzuje zapiski Arsenija III Čarnojevicia (1633-1706), który wyprawił się do Jerozolimy pod koniec 1682 r. W 1705 r. Ziemię Świętą odwiedził Jerotej Račanin, który spisaną dwadzieścia dwa lata później relację Podróż do miasta Jerozolimy (Пymauacmвuje ка градy Јерусалиму Јеротеја, јеромонаха рачанинскаго, 1727) uatrakcyjnił legendami. Opis podróży do Ziemi Świętej Opis Jerozolimy (Onисаније Jерусалима, 1748) sporządził również Hristofor Žefarović (1710-1753), a Jovan Rajić (1726-1801) w relacji Podróż morska (Мореплаваније, 1758) utrwalił wyprawę przez Morze Czarne do klasztoru na górze Athos.

11 Ibidem.

12 Zaharije Stefanović Orfelin (1726-1785) podkreślał korzyści, jakie społeczeństwu przynoszą rozmowy o kuli ziemskiej i zamieszkujących ją narodach. Wzorcem do naśladowania dla późniejszych twórców literatury podróżniczej stało się dzieło Dositeja Obradovicia (1739-1811) Życie i przygody (Живот и прикљученија, 1783), łączące autobiografię z wrażeniami z podróży po Europie.

13 Gatunek ten reprezentują: Życie (Жumuje, 1823) Gerasima Zelicia (1784-1828), Podróż ро Serbii (Путешествије по Србији, 1828) Joakima Vujicia (1772-1847), Pamiętniki (Мемоари, 
jest Ljubomir Nenadović (1826-1895), który utrwalił wrażenia ze swoich wojaży $\mathrm{w}$ formie listów ${ }^{14}$.

Na początku XX w. i po I wojnie światowej dzieła o charakterze podróżniczym tworzyli najwybitniejsi uczestnicy serbskiego życia literackiego, m.in. Isidora Sekulić (1877-1958) — autorka Listów z Norwegii (Писма из Норвешке, 1913), Jovan Dučić (1871-1943) — twórca impresji z wielu krajów, wydanych w 1940 r. w tomie Miasta i chimery (Градови и химере), czy Jelena Dimitrijević (1862-1945) - kultywująca w swojej prozie ${ }^{15}$, zapoczątkowaną Listami z Niszu o haremach (Писма из Ниша о харемима, 1897), fascynację obcymi krajami i kulturami. Wielu pisarzy serbskich łączyło zainteresowanie nowo powstałym na gruzach monarchii austro-węgierskiej państwem południowosłowiańskim ${ }^{16}$ — Królestwem Serbów, Chorwatów i Słoweńców (przemianowanym w 1929 r. na Królestwo Jugosławii) - z relacjami z innych krajów. Należeli do nich m.in. Miloš Crnjanski (1893-1977) — autor Listów z Paryża (Писма из Париза, 1921), Miłości w Toskanii (љубав y Тоскани, 1930), Książi o Niemczech (Къига о Немачкој, 1931), Ivo Andrić (1892-1975) — posiadający w swoim dorobku impresje z różnych zakątków Europy oraz z krajów pozaeuropejskich ${ }^{17}$, a tak-

1834) Proty Mateja Nenadovicia (1777-1854) oraz Listy serbskiego podróżnika (Писма србског путника, 1850) Bogoboja Atanackovicia (1826-1858).

${ }^{14}$ Ljubomir Nenadović jest autorem Listów z Greifswaldu (Писма из Грајфсвалда, 1850), Listów ze Szwajcarii (Писма из Швајцарске, 1852), Listów z Włoch (Писма из Италије, 1869), Listów z Niemiec (Писма из Немачке, 1874) і Listów z Cetynia (Писма са Цетиъа, 1889).

15 Jelena Dimitrijević jest autorką Listów z Salonik (Писма из Солуна, 1918), Listów z Indii (Писма из Индије, 1928), Listów z Egiptu (Писма из Мисира, 1929), powieści: Nowe (Нове, 1912) i Nowy Świat lub rok w Amеryce (Нови свет или у Америци годину дана, 1934) oraz prozy роdróżniczej Siedem mórz i trzy oceany. Podróż dookoła świata (Седам мора и три океана. Путем око света, 1940).

${ }^{16}$ Autorami tekstów prasowych byli m.in. Dragiša Vasić - Dwa miesiace na poludniowostowiańskiej Syberii (Два месеиа у југословенском Сибиру, 1921), Stanislav Krakov — Przez południowa Serbię (Кроз Јужну Србију, 1926) i Grigorije Božović - Zapiski na marginesie (Узгредни записи, 1926), Prawdy wyryte (Урезане истине, 1930), Сиdowne zakatki (Чудесни кутови, 1930), Z siodła i kulbaki (Са седла и самара, 1930). Miloš Crnjanski przedstawił swoje spojrzenie na zjednoczone państwo w reportażach z lat 1923-1928, znanych współczesnemu czytelnikowi jako Nasze niebiosa (Наша небеса). Stanislav Vinaver zawarł impresje podróżniczo-eseistyczne w książce Гоч Гори (1927), podczas gdy jego Żywe ramy (Живи оквири, 1938) dokumentują pobyt pisarza m.in. w centralnej Serbii i na wybrzeżu dalmatyńskim. Cykl Z podróży po Serbii (C nуma nо Србијu) wydany jako Widok z okna wagonи (Панорама са вагонског прозора, 1939) należy do dorobku Momčila Nastasijevicia. Utwory poświęcone podróżom po Serbii, Czarnogórze, Chorwacji, Słowenii, Bośni i Hercegowinie stworzył natomiast Rade Drainac (por. Р. Драинац, Путујем, путујем. Путописи и репортаже. Дела, шести том, Нови Сад 1999).

${ }^{17}$ И. Андрић, Кроз Аустрију, [w:] idem, Предели и стазе. Путописна проза, Београд 2002, s. 47-53; idem, Швајска, [w:] idem, Предели и стазе..., s. 56-59; idem, Немачка, [w:] idem, Предели и стазе..., s. 60-63; idem, Португал, зелена земља, [w:] idem, Предели и стазе..., s. 146-149; idem, Eгипат, [w:] idem, Предели и стазе..., s. 253-255; idem, Сусрет у Кини, [w:] idem, Предели и стазе..., s. 256-260. 
że Rade Drainac (1899-1943) ${ }^{18}$, który utrwalił refleksje z krajowych i europejskich wojaży. Utwory Rastka Petrovicia (1898-1949) z lat 20. i 30. poświęcone są różnym krajom oraz kontynentom, a synkretyczne dzieło Ludzie mówia (Љydu говоре, 1931) łączy „opis podróży, powieść i opowiadanie z elementami eseju i autobiografii”"19.

Przegląd kierunków podróży do Europy Zachodniej pozwala zauważyć, że celem refleksji podróżniczej i kulturoznawczej pisarzy serbskich stawały się najczęściej Niemcy ${ }^{20}$, Francja ${ }^{21}$ oraz Włochy ${ }^{22}$, które były dla Serbów krajem geograficznie bliskim, stanowiącym część „исте »медитеранске инспирације«”23. Współcześnie coraz większe znaczenie zyskują wyprawy poza Europę - do Afryki ${ }^{24}$, krajów Ameryki Południowej ${ }^{25}$ i Azji ${ }^{26}$.

Odległe miejsce na trasie podróży pisarzy serbskich zajmowała Hiszpania, która zarówno Serbom, jak i innym cudzoziemcom jawiła się jako tajemnicza

18 Р. Драинац, op. cit.

19 С. Јаћимовић, Путописи српске авангарде, Београд 2005, s. 22.

20 Љ. Ненадовић, Писма из Немачке (1874); Д. Васић, Утисии из данашње Немачке (1923); С. Винавер, Немачка у вреюу (1924); М. Црњански, Кюига о Немачкој (1931); В. Крњевић, Берлинске баладе (1960), Барокна свита о паду Берлина (1998).

${ }^{21}$ М. Црњански, Писма из Париза; Ј. Дучић, Градови и химере; М.Ј. Савић, Путопис: занимљивост из Франиуске. Либије и Ирака, Београд 2010.

22 О. Ступаревић, Српски путопис о Италији, Београд 1976. Olga Stuparević w swoim kanonicznym studium wymienia osiemdziesiąt cztery relacje z podróży do Włoch, które w latach 1788-1973 wzbogaciły podróżopisarstwo serbskie.

23 П. Палавестра, Оданост Југу, „Политика”, 21.06.1971, суt. za: О. Ступаревић, Српски путопис о Италији, Београд 1976, s. 103.

24 Przed II wojną światową Rastko Petrović opublikował relację z podróży do Afryki (Африка, 1930). Po Zambii podróżował Đoko Stojčić (Đ. Стојчић, Путовање по Замбији, Ваљево 1981). Mileta Prodanović w książce Oko wędrowca (Око на nуmy) zebrał wrażenia z wielu zakątków Europy i Afryki Północnej. Z kolei Egipt interesował już serbskich pisarzy-modernistów. Por. M. Кох, Модернистичке и постмодернистичке репрезентације египатске стварности у српској књижевности 20. века (Јелена Димитријевић-Јован Дучић-Исидора Бјелииа), [w:] Кюижевност и стварност, Зборник МСЦ, t. 36, nr 2, Београд 2007, s. 265 277. Współczesną relację z podróży do Egiptu opublikowała np. Milka Lučić (М. Лучић, Моj скарабеј, сентиментални дневник с путовања по Египту, Београд 2003).

25 М. Кујунџић, Панама, мост света, Нови Сад 1978.

26 Por. М. Старчевић, Мирис кобре: путопис, Шабац 2004; В. Лазић, Тумарање земљом осмеха: романсирани путопис по Тајланду, Београд 2006; Д. Попноваков, Милијарда: путопис из Кине, Нови Сад 1981; Љ. Ђидић, Чудесна Кина, Крушевац 1988; Р. Пушић, Капија од жада: путописи Срба о Кини, Београд 1998; С. Владиславић, Поднебеско иарство: Срби о Кини (1725-1940), Београд 2006; М. Павловић, Кина - око на пут, Београд 1982; idem, Путеви до храма: путописи, записи и иртежи из Индије, Ниш 1991; С. Пешић, Катманду, Београд 1982; idem, Светло острво, Београд 1999. Wrażenia z Azji utrwaliła Olga Moskovljević w książce Kraje kwiatu lotosu. Azja poludniowo-wschodnia (Земље лотосовог иявета. Југоисточна Азија, 1990). Z kolei Momo Dimić w książce Wędrowiec bez litości (Путник без милости, 1991) łączy impresje z Neapolu, Chin, Jerozolimy, Syberii i Rzymu. 
kraina „zawieszona między Europą i Afryką, [...] Zachodem i Orientem”27, odgrodzona „fosami mórz i ostrokołem Pirenejów”28. Obraz tego kraju cudzoziemcy budowali w swojej świadomości przez dziesięciolecia głównie na podstawie literatury ${ }^{29}$, gdyż odległość i bariera w postaci pasma Pirenejów nie sprzyjała podejmowaniu trudu wyprawy.

Hiszpania jako przestrzeń geograficzno-kulturowa znalazła się w sferze zainteresowania Serbów już w XVIII w. ${ }^{30}$, lecz jako kierunek podróży zyskała znaczenie dopiero w XX w., zwłaszcza po I wojnie światowej, gdy stała się celem wyjazdów wybitnych pisarzy, przebywających tam w charakterze dyplomatów, dziennikarzy czy też turystów ${ }^{31}$. Wydarzeniem koncentrującym uwagę serbskiej (i jugosłowiańskiej) opinii publicznej była hiszpańska wojna domowa (1936-1939), której obraz utrwalili pisarze korespondenci ${ }^{32}$ oraz uczestniczący w walkach ochotnicy z Jugosławii ${ }^{33}$.

W pierwszych latach po II wojnie światowej rezolucja Zgromadzenia Ogólnego ONZ, wzywająca do zawieszenia stosunków dyplomatycznych z reżimem gen. Francisco Franco ${ }^{34}$, ograniczyła podróże cudzoziemców za Pireneje. Pisarze z socjalistycznej Jugosławii mieli okazję zwiedzania tego kraju dopiero w latach 70. XX w. Swoje wrażenia z podróży spisał wówczas dziennikarz z Nowego Sadu Miodrag Kujundžić (1926-1998) w relacji Białe domy i czarne byki (Беле куће и ирни бикови) $)^{35}$. Do tamtych czasów powróciła wspomnieniami dziennikarka

27 J. Winczakiewicz, Andaluzja i Kastylia. Antologia poezji hiszpańskiej XX wieku, Londyn 1963, s. 5.

28 Ibidem.

${ }^{29}$ Wśród tych dzieł znalazły się: Rękopis znaleziony w Saragossie (Manuscrit trouvé a Saragosse, 1805) Jana Nepomucena Potockiego (1761-1815), Opowieści Alhambry (Tales of the Alhambra, 1829) Washingtona Irvinga (1783-1859), Podróż do Hiszpanii (Voyage en Espagne, 1843) Teofila Gautiera (1811-1872), opowiadanie Carmen (1846) Prospera Mérimée (1803-1870), które stało się kanwą dla opery Bizeta oraz Listy o Hiszpanii (Письма об Испании, 1847-1849) Wasyla Botkina (1822-1869).

30 Zainteresowanie to przejawiało się próbą popularyzowania wśród Serbów Don Kichota przez wprowadzanie wątków dotyczących tego bohatera do literatury serbskiej. Рor. Ј. Стојановић, Сервантес у српској къижевности, Баоград 2005, s. 17-33, 148-188.

31 Jovan Dučić i Ivo Andrić przebywali w Hiszpanii jako przedstawiciele służb dyplomatycznych. Miloš Crnjanski dwukrotnie (w roku 1933 i 1937) wyjeżdżał jako korespondent gazety „Vreme”. Wrażenia z Toledo i Kordoby pozostawił Stanislav Krakov. Jako turyści odwiedzili Hiszpanię Rastko Petrović i Jelena Dimitrijević, która zawarła swoje wrażenia w książce Ceдaм мора и три океана. Путем око света (1940).

32 Reportaże z czasów wojny domowej pisał w 1937 r. Miloš Crnjanski. Natomiast książka Oto Bihalji-Merina Шпанија између смрти и рађања ukazała się po serbsku dopiero w $1946 \mathrm{r}$., wcześniej pojawiła się po niemiecku i angielsku.

${ }^{33} \mathrm{~W}$ latach 70. XX w. ukazało się m.in. pięć tomów wspomnień ochotników składających się z ponad dwustu zapisów z czasów wojny domowej - Шпанија (1936-1939). Зборник сећања југословенских добровољаца у шпанском рату, red. Ч. Капор, Београд 1971.

34 T. Miłkowski, P. Machcewicz, Historia Hiszpanii, Wrocław 1998, s. 394.

35 М. Кујунџић, Беле куће и ирни бикови, „Летопис Матице српске” 147, 1971, nr 407, z. 4, s. 197-231. 
„Politiki”36 Milka Lučić (ur. 1949), która odwiedziła Hiszpanię jesienią 1977 r., a swoje wrażenia z pobytu zawarła w utworze Nasz przewodnik Don Kichot (Haw водич Дон Кихот), zamieszczonym w opublikowanej w 2010 r. książce Ceremonia śródziemnomorska (Медитеранска церемонија) ${ }^{37}$.

Z 1978 r. pochodzą zapiski malarza, reżysera i scenarzysty ${ }^{38}$ Miodraga Popovicia (1923-1996). Sporządzone w latach 1971-1981, a opublikowane z inicjatywy rodziny Popovicia i przy wsparciu ministerstwa kultury Serbii Dzienniki z podróży (Путописни дневници $)^{39}$, upamiętniające dziesiątą rocznicę śmierci artysty, zawierają relacje z jego pobytu w siedmiu krajach: w Chinach, Tajlandii, Indiach, Iranie, Meksyku, USA oraz Hiszpanii. Utwory te, poza wzmiankami o sztukach plastycznych i architekturze, dostarczają wiadomości na temat geografii, religii, polityki, historii, archeologii, sportu, zasad żywienia i zwyczajów; oferują zatem informacje z różnych dziedzin, które składają się na sferę ludzkich doświadczeń.

Zawarta w Dziennikach z podróży relacja, zatytułowana Podróż do Hiszpanii (Пуm у Шnанију $)^{40}$, traktuje o tygodniowej wycieczce, którą Popović odbył wraz z biurem podróży „Putnik” w dniach 4-11 września 1978 r., gdy kraj — po trwającej niemal cztery dekady dyk taturze frankistowskiej — zaczął otwierać się na cudzoziemców oraz własnych emigrantów ${ }^{41}$. Wyprawa Popovicia stanowiła

${ }^{36}$ W „Politice” ukazywały się artykuły M. Lučić poświęcone m.in. twórczości Iva Andricia. Por. eadem, Писаи и юегове «Свеске», „Политика” 78, nr 24377 (17.08.1981), s. 10; eadem, Са ли је Андрић споран: шта је познати писаи написао у свом тексту о Албанији из 1939. и зашто је неприхватљиво поређење између юега и Кадареа, „Политика” 84, nr 26350 (13.02.1987), s. 13; еаdem, Дело Иве Андрића, „Политика” 85, nr 26960 (24.10.1988), s. 12; eadem, Андрић као дипломата, „Политика” 89, nr 28391 (21.10.1992), s. 15; еаdет, Замало на отпаду: Како је спасена Андрићева дисертаиија, „Политика” 93, nr 29693 (21.06.1996), s. 22; eadem, Европа се зауставила у Травнику, „Политика” 94, nr 29913 (2.02.1997), s. 18; eadem, Дневник из Сокобағе, „Политика” 95, nr 30390 (2.06.1998), s. 23; еadem, Андрић о Космету, „Политика” 104, nr 33912 (5.04.2008), s. 10.

${ }^{37}$ М. Лучић, Наш водич Дон Кихот, [w:] еаdет, Медитеранска иеремонија. Сентиментални дневник с путовања по Средоземљу и юеговим имагинарним рукавиима, Београд 2010, s. 94-126.

${ }^{38}$ M. Popović wyreżyserował następujące filmy: Човек из храстове шуме (1963), Рој (1966), Хасанагинииа (1967), Делије (1969), Бурдуш (1970), Природна граница (1970).

${ }^{39}$ М. Поповић, Путописни дневници, Београд 2006. Wszystkie cytaty pochodzą z tego wydania.

${ }^{40}$ М. Поповић, Пут у Шпанију, [w:] idem, Путописни дневници, s. 138-157.

41 Juan Carlos koronowany na króla Hiszpanii po śmierci gen. Franco zadeklarował chęć przezwyciężenia podziałów wojny domowej. Demontowanie instytucji frankistowskich, uwalnianie więźniów politycznych, legalizowanie partii (w tym w kwietniu 1977 r. partii komunistycznej) nie obyło się bez przemocy politycznej. Zwycięzcami wyborów powszechnych z 15 czerwca 1977 r. zostały Socjalistyczna Partia Robotnicza Hiszpanii (PSOE) oraz Unia Demokratycznego Centrum (UCD) Adolfa Suáreza, którego zwycięstwo oraz zdolność opozycji do kompromisu pozwoliły wprowadzić reformy. Za: S. Barton, Historia Hiszpanii, przeł. A. Mścichowska, M. Mścichowski, Warszawa 2011, s. 301-305. 
urzeczywistnienie jego marzenia ${ }^{42}$ o obejrzeniu oryginałów ulubionych obrazów. Fascynowało go bowiem malarstwo hiszpańskie wielu epok oraz nowoczesna sztuka iberyjska, którą miał okazję podziwiać na wielu wystawach, jednak zawsze poza Hiszpanią. O spotkaniu z twórczością Francisco Goi (1746-1828) Popović wspomina już w wydanym w 1954 r. zbiorze Zderzenia $i$ harmonie (Судари и хармоније) ${ }^{43}$, w którym opisuje m.in. paryską wystawę grafik Goi, na którą trafił dzięki znajomemu Hiszpanowi, mieszkającemu w Paryżu od czasów zakończenia wojny domowej. Serbski artysta ocenił wówczas grafiki Goi jako monotonne i szablonowe ${ }^{44}$.

W programie wyjazdu Popovicia, oprócz pobytu w stolicy kraju, znalazło się zwiedzanie kompleksu pałacowo-klasztornego w miasteczku San Lorenzo de El Escorial pod Madrytem, wizyta w Dolinie Poległych (Valle de los Caídos), upamiętniającej ofiary wojny domowej, oglądanie zabytków Toledo oraz poznanie arabskiego dziedzictwa Andaluzji. Przedmiotem zainteresowania Popovicia, który zrezygnował z podróży do Andaluzji na rzecz dłuższego pobytu w Madrycie, stały się głównie kolekcje malarstwa z muzeum Prado oraz Muzeum Sztuki Współczesnej, dzieła malarskie zgromadzone w klasztorze Eskurial, a także zbiory z muzeów i świątyń Toledo.

José Ortega y Gasset stwierdził, że malarstwo hiszpańskie aż do końca XVIII w. było „prowincją ogromnego malarskiego kontynentu, który stanowiła sztuka włoska" ${ }^{\text {"45 }}$, a na miano prawdziwych geniuszy zasłużyli tylko trzej twórcy hiszpańscy: José Ribera, Francisco Zurbarán i Diego Velázquez ${ }^{46}$. Zastanawiając się nad czynnikami odróżniającymi malarzy hiszpańskich od przedstawicieli tej dziedziny sztuki z innych krajów, Popović dochodzi do wniosku, że termin „,malarstwo hiszpańskie" można odnieść głównie do twórczości Goi, którego ironiczna i ekscytująca sztuka ${ }^{47}$ splata się z przeszłością i teraźniejszością tego kraju. Popović nazywa Goyę buntownikiem, wizjonerem i prześmiewcą ${ }^{48}$, uznaje go za wzór dla tych twórców i odbiorców sztuki, którzy postrzegają ją jako akt moralny. Serbski malarz podkreśla więź Goi z rzeczywistością Hiszpanii i podobieństwo utrwalonych w jego dziełach postaci do jej współczesnych mieszkańców, którzy mają podobny wyraz twarzy, przybierają analogiczne pozy i w zbliżony sposób wyrażają emocje, zaś tło poszczególnych dzieł Goi jest tak mocno związane z Madrytem, że pozwala współczesnym odbiorcom dzieł rozpoznać różne zakątki hiszpańskiej stolicy.

42 М. Ђорђевић, Да ме је Михиз видео... Белешке, иртежи и приче из Мексика, Ирана, са Тајланда, Америке..., http://www.politika.rs/rubrike/Kultura/t13627.It.html (dostęp: 3.12.2006).

${ }_{43}$ М. Поповић, Судари и хармоније, Нови Сад 1954.

44 Ibidem, s. 28.

45 J. Ortega y Gasset, Velázquez i Goya, przeł. R. Kalicki, Warszawa 1993, s. 149.

46 Ibidem, s. 90.

47 М. Поповић, Судари и хармоније, s. 178.

48 Ibidem, s. 28. 
Popović w swojej relacji zawarł spostrzeżenia dotyczące konkretnych dzieł malarskich, które obejrzał w hiszpańskich muzeach — m.in. zaakcentował związek Ribery i Zurbarana z malarstwem zagranicznym. Twórczość Velázqueza, który „dał swoje imię odkryciu w świecie światła"49, nazwał sztuką stricte hiszpańską ze względu na jej silne akcenty katolickie. Wśród dzieł malarza, którego interesowały zarówno pejzaże, sceny rodzajowe, jak i motywy alegoryczne, sakralne i mitologiczne ${ }^{50}$, Popović wyróżnił obraz z 1630 r. zatytułowany Kuźnia Wulkana, który ujawnia jedyną, zdaniem Popovicia, słabość mistrza, jaką była kompozycja, sprawiająca wrażenie, że dzieło jest zawieszone pomiędzy niebem a ziemią. Autor relacji podkreślił, że prace Velázqueza, który malował przede wszystkim rodzinę i dwór króla Filipa $\mathrm{IV}^{51}$, należy podziwiać z bliska, gdyż tylko wtedy widoczne są szczegóły techniczne — od delikatnego muśnięcia do zdecydowanych ruchów pędzlem. W salach z malarstwem włoskim Popović oglądał dzieła Tycjana i Rubensa. Przyjrzawszy się kolekcji prac mistrzów flamandzkich, skonstatował, że ten ilościowo bardzo skromny zbiór jest jednak bardzo znaczący ze względu na wartość zgromadzonych obrazów. Popović za najpiękniejsze dzieło Rogiera van der Weydena (1399/1400-1464) uznał Zdjęcie z krzyża, które potwierdza charakterystyczną dla tego malarza umiejętność tworzenia kompozycji, modelowanych niczym grupy rzeźb ${ }^{52}$; podkreślił też wyższość prac Pietera Breugla nad dziełami Hieronima Boscha.

W Muzeum Sztuki Współczesnej na pozytywną ocenę Popovicia zasłużyło jedynie pięć obrazów, w tym cztery dzieła Pabla Picassa i jedno Salvadora Dalego. Serbski artysta stwierdził, że malarstwo hiszpańskie z początku XX w., z wyjątkiem prac kilku uznanych twórców, takich jak Salvador Dalí, Pablo Picasso czy Juan Miró, nie prezentuje wysokiego poziomu. W jego ocenie malarze chorwaccy, np. Josip Račić (1885-1908) i Miroslav Kraljević (1885-1913), mogliby z powodzeniem konkurować z twórcami dzieł zgromadzonych w tym madryckim muzeum. Popović wymienił także nazwiska tych twórców, których dzieła były w czasie jego wizyty niedostępne dla zwiedzających ${ }^{53}$.

Popović zdecydował się ponadto na samodzielne odwiedzenie galerii Eskurialu, gdzie zgromadzono prace Boscha, Dürera, Tycjana, Ribery, Zurbarana, El Greca oraz tapiserie tworzone na podstawie projektów Goi. Program wycieczki, w której wziął udział, uwzględniał również krótki postój w miejscu wiecznego spoczynku gen. Franco - w Dolinie Poległych, kompleksie architektonicznym, który tworzy wykuta w skale bazylika i górujący nad nią krzyż. W opinii Hiszpa-

49 A. de Botton, Sztuka podróżowania, przeł. H. Pustuła, Warszawa 2010, s. 175.

50 О. Бихаљи-Мерин, Јединство света у визији уметности, Београд 1974, s. 99.

${ }^{51}$ Ibidem.

${ }^{52}$ M. Levey, Od Giotta do Cézanne'a. Zarys historii malarstwa zachodnioeuropejskiego, przeł. M. Bańkowska, S. Bańkowki, Warszawa 1972, s. 74.

${ }^{53}$ W tej części muzeum, gdzie zgromadzono prace takich artystów, jak Luis Feito (1929), Manuel Millares (1926-1972), Antoni Tapies i Puig (1923), Rafael Canogar (1935) oraz Juan Genovés (1930), trwał w tym czasie remont. 
nów Dolina służy upamiętnieniu wszystkich ofiar wojny domowej, lecz Popović podkreślił nierównomierny wkład każdej ze stron konfliktu w powstanie obiektu - obrońcy Republiki wykonanie obiektu przypłacili życiem, frankiści natomiast wnieśli w jego realizację głównie wizje artystyczne oraz dozór nad pracującymi więźniami.

Oprócz San Lorenzo de El Escorial Popović zwiedził dawną stolicę kraju - Toledo. W trakcie spaceru po mieście nad Tagiem m.in. znalazł się na placu Zacodóver, obejrzał zamek, synagogi, most Alcántara oraz Pałac Tavera z kolekcją obrazów El Greca. W otwartym w 1912 r. muzeum, ulokowanym niedaleko miejsca, w którym niegdyś prawdopodobnie znajdował się dom malarza z Krety, Popović podziwiał wizerunki dwunastu apostołów oraz dzieło Widok i plan Toledo z 1610 r., na którym oprócz perspektywicznego pejzażu miejskiego plan miasta znalazł się w dłoni młodzieńca o rysach charakterystycznych dla wszystkich postaci malowanych przez El Greca. Pobyt w muzeum upamiętniła fotografia, służąca strategii materializacji i prywatyzacji wspomnień ${ }^{54}$.

W kaplicy toledańskiego kościoła św. Tomasza autor relacji obejrzał obraz Pogrzeb hrabiego Orgaza - pierwsze z datowanych dzieł, namalowanych przez El Greca w Toledo. Ten portret grupowy, uważany za najwspanialszą pracę artysty jako portrecisty, należy w pewnej mierze do gatunku obrazów religijnych ${ }^{55}$. Zdaniem malarza serbskiego żadne dzieło nie może równać się z tym obrazem, posiadającym jednocześnie wymiar rzeczywisty i nadnaturalny. W monumentalnej katedrze Popović zwrócił uwagę na cykl obrazów El Greca przedstawiający apostołów, których postaci, jego zdaniem, prezentują się dużo gorzej niż dzieła o tej samej tematyce zebrane w domu-muzeum artysty. W katedrze Popović zamyślił się nad dziełem Obnażenie Chrystusa z szat. Obraz ten, mający siłę wyrazu najlepszych prac artysty, zdaniem Popovicia ustępuje jednak Pogrzebowi, który autor Dzienników umieścił na szczycie swojej listy najwspanialszych dzieł malarstwa światowego ${ }^{56}$.

Popović w madryckim lokalu Café de Chinitas obejrzał także spektakl flamenco. W oryginalnej formie flamenco stanowi pieśn skargi. Pochodząca z głębi duszy skarga opowiada o nieszczęśliwej miłości, opuszczeniu i braku nadziei, a przez osobliwość tonów i niezwykły rytm różni się od muzyki europejskiej. Flamenco może trwać godzinami, a nawet całymi dniami. Słuchaczom udziela się ekstaza śpiewającego, towarzyszą mu, zachęcają, nadają rytm, klaszczą, wykonując wyraziste ruchy ramionami i całym ciałem. Dlatego flamenco jest przeżyciem zbiorowym ${ }^{57}$. W klubach flamenco (tablaos) tancerki w barwnych

54 J. Urry, Spojrzenie turysty, przeł. A. Szulżycka, Warszawa 2007, s. 205.

55 J. Gállego, „Pogrzeb hrabiego Orgaza” jako portret, [w:] A. Biała, Literatura i malarstwo. Korespondencja sztuk, Warszawa-Bielsko-Biała 2010, s. 314.

${ }^{56}$ М. Поповић, Треба ћутати и стрепети, [w:] М. Глигоријевић, Одговор Миће Поповића, Београд 1984, s. 112.

57 B. Hintzen-Bohlen, Andaluzja. Sztuka i architektura, przeł. H. Hartwig, [b.m.w.] 2008, s. $426-427$. 
strojach czarują publiczność klaskaniem, wirującymi spódnicami i przytupywaniem. Wspierają je partnerzy, którzy obcasami wystukują rytm. Ich krzykliwa pieśń zlewa się z dźwiękami gitary. Tego rodzaju inscenizacje nie mają jednak wiele wspólnego z prawdziwym flamenco — jedną z najbardziej pierwotnych form muzyki hiszpańskiej, która żywi się spontaniczną inspiracją i atmosferą intymności. Prawdziwe flamenco można przeżyć jedynie w małym gronie, kiedy jeden z wykonawców, przy wtórze zgromadzonych, zaczyna śpiewać tradycyjne lub nieco zmienione słowa różnych pieśni ${ }^{58}$. Popović po spektaklu wyraził opinię, iż jego ulubiony malarz Francisco Goya prawdopodobnie nie byłby zachwycony komercyjnym charakterem przedstawienia.

Malarz serbski zdecydował się też obejrzeć walkę z bykami, która w Madrycie odbywa się na Plaza Monumental de las Ventas — arenie zbudowanej w stylu arabskim po I wojnie światowej. Na trybunie zajął zacienione miejsce, w którego pobliżu matador zadaje zwierzęciu śmiertelny cios. Autor Dzienników z podróży podkreślił wielkie emocje wywołane przez wydarzenia na arenie, utrwalił również reakcje publiczności. Wprawdzie udało mu się wytrwać do końca spektaklu, jednak trybunę opuszczał oszołomiony i wyczerpany widokiem krwi i cierpienia zwierząt.

Oprócz muzeów Madrytu, galerii Eskurialu, Doliny Poległych, zabytków i muzeów Toledo, spektaklu corridy i flamenco Popović zapoznał się także z topografią hiszpańskiej stolicy, którą oglądał wraz z jugosłowiańską wycieczką przez szybę autokaru, a po wyjeździe grupy do Andaluzji, poruszając się po Madrycie taksówką lub spacerując. Madryt wydał się pisarzowi czystszy od innych stolic europejskich, ale mało przyjazny. Popović podkreślił podobieństwo jego architektury do zabudowy niektórych dzielnic Rzymu, akcentując przy tym, że fakt ten nie stał się źródłem inspiracji artystycznej dla współczesnych malarzy hiszpańskich, takich jak Pablo Picasso, Juan Miró i Juan Gris, którzy wyjechali z Hiszpanii.

W parku na Plaza de España Popović podziwiał pomnik Cervantesa, przedstawiający pisarza wraz z bohaterami jego słynnej powieści. Imponujący monument wywołał u serbskiego artysty wspomnienia z dzieciństwa, gdy jako odbiorca dziecięcej wersji Don Kichota nie potrafił wybaczyć autorowi, że ośmieszył swego bohatera, którego jako młody czytelnik uważał za najlepszego z ludzi.

Wędrówki po hiszpańskiej stolicy zaprowadziły Popovicia przez most na rzece Manzanares do Rynku (Plaza Mayor). Autor relacji, który przybył do Hiszpanii trzy lata po śmierci gen. Franco, zawarł w swym tekście też uwagi i spostrzeżenia na temat panującego prawie cztery dziesięciolecia reżimu. Myśl o dyktaturze, co oczywiste, towarzyszyła pisarzowi w trakcie pobytu w Dolinie Poległych, lecz pojawiła się także na oświetlonym wrześniowym słońcem madryckim placu, gdzie w kwietniu 1939 r. dyktator świętował zwycięstwo w wojnie domowej.

58 Ibidem, s. 426. 
Popović na madryckich placach i ulicach przyglądał się ludziom, którzy wydawali mu się tak samo weseli i serdeczni, jak poznani w czasie pobytów za granicą Francuzi czy Włosi. Autor dostrzegł wiele analogii pomiędzy Hiszpanią a Francją oraz Hiszpanią a Włochami, które poznał dzięki stypendiom w latach 50. XX w. Starsi Hiszpanie, dyskutujący na ulicach Madrytu, zachowywali się jak Włosi i Francuzi, młodzi zaś okazywali sobie czułość tak samo jak ludzie w Paryżu. Ze względu na stosunek dorosłych do dzieci Hiszpania przypominała mu Włochy, ponieważ w obu krajach dzieci wydawały mu się bezkarne, nikt nie zwracał uwagi na ich krzyki i zabawy do późnych godzin nocnych. Dachy podmadryckich domów kojarzyły się Popoviciowi z podobnymi konstrukcjami w dolinie Loary, a madrycki „pchli targ” — El Rastro — nie różnił się jego zdaniem niczym od podobnych miejsc w Paryżu lub Rzymie.

Wędrując nocą przez opustoszałe ulice hiszpańskiej stolicy, Popović odniósł wrażenie, jakby wszystko to, co zobaczył w ciągu wrześniowego tygodnia, oglądał już kiedyś, przed pięćdziesięciu laty. Widoki ze sfery snów przechodzące w realność zrodziły u niego pytania o granice pomiędzy obrazem a wizją. Wizja jest bowiem pod wieloma względami bliska fenomenowi snu, jest porównywalna do niego nie tylko jako podróż w inny świat lub odwiedziny w innym świecie, ale też jako fenomen obrazowy. Wizja jednak, odmiennie niż sen, zapewnia odbiorcy „objawienie”, które sprawia, że dostępne stają się dla niego rzeczy, których nie mógłby doświadczyć w tym świecie. Dlatego doświadczenie wizji nasuwa pytanie o to, czy było ono prawdziwe, czy też tylko do prawdziwości pretenduje, czy chodziło o interwencję z zaświatów, czy też o urojenie ${ }^{59}$.

Mimo fascynacji sztuką, zwłaszcza malarstwem, które stało się głównym celem wycieczki do Madrytu, Popović doświadczył przeżyć właściwych typowo turystycznej wyprawie. Przelot z Belgradu (z międzylądowaniem w Zagrzebiu) zakłóciły trudne warunki atmosferyczne. Turbulencje na terytorium Francji nie pozostały bez wpływu na pasażerów samolotu, którzy cierpieli na zwykłe w takiej sytuacji dolegliwości. Z powodu złej pogody pasażerowie boeinga 727 ujrzeli ziemię hiszpańską dopiero tuż przed lądowaniem, przez co zostali pozbawieni przyjemności napawania się widokiem niezwykłej kolorystyki („од златног окера и смеђих сенки" [s. 141]) Półwyspu Iberyjskiego. Po przylocie do Madrytu Popović doświadczył też trudności z zaaklimatyzowaniem się, gdyż późniejszy wschód słońca utrudniał poranne wstawanie.

Popović odnotował w swojej relacji kilka sytuacji, w których musiał poradzić sobie bez znajomości języka hiszpańskiego. Brak umiejętności komunikowania się w miejscowym języku nie przeszkodził mu jednak w spożyciu wyśmienitej kolacji w niewygórowanej cenie w restauracji położonej w pobliżu placu Puerta del Sol. Serbski artysta próbował różnych specjałów lokalnej kuchni, jadł ryby

${ }^{59}$ H. Belting, Antropologia obrazu. Szkice do nauki o obrazie, przeł. M. Bryl, Kraków 2007, s. 92 . 
oraz owoce morza, smakowały mu wina, a szczególnie przypadła mu do gustu słynna szynka iberyjska („што су добри ови сендвичи с пршутом” [s. 155]).

Popović poczynił również kilka spostrzeżeń dotyczących języka hiszpańskiego. Jak wiadomo, każdy język narodowy ma swoje „słowa kluczowe”, „symbole kolektywne”, pisane wielką literą dla podkreślenia respektu, jakim się je obdarza. W polskiej tradycji są to słowa „Bóg”, „Honor”, „Ojczyzna”, z kolei w tradycji wywodzącej się od rewolucji francuskiej: „Wolność”, „Równość”, „Braterstwo" 60 . Miodrag Popović na ławce w madryckim parku Retiro odkrywa, że dla Hiszpanów słowami tymi są: „Bóg”, „Ojczyzna”, „Sprawiedliwość” (Dios, Patria, Justicia).

Dla turysty głównym źródłem schematów poznawczych są przewodniki, które dostarczają ,instrukcji obsługi świata” i spotykanych w nim Innych oraz spełniają funkcje szczególnego rodzaju didaskaliów: opisu miejsc, ich hierarchizacji, wartościujących etykiet, wzorców zachowan ${ }^{61}$. W tego rodzaju publikacjach dba się o dostarczanie turyście przyjemności, demonstrując sposoby odkrywania uroków poznawanej krainy ${ }^{62}$. Objaśnienia z przewodników, podobnie jak opisy zawarte w dziełach literackich, kreują swoje własne światy. Ich relacja do rzeczywistości pozatekstowej jest sprawą konwencji, która rozstrzyga o tym, że odbiorca godzi się na fikcyjność przekazu bądź przyjmuje, iż są te przekazy obiektywne i bezpośrednio odnoszą się do rzeczywistości takiej, jaką ona jest, bez ingerencji patrzącego i opisującego podmiotu ${ }^{63}$. Serbski artysta-turysta podkreśla, że bedekery o Hiszpanii, które kupił w tym kraju i przeglądał w wolnych chwilach, napisane są znakomitym językiem.

Popović czyni także spostrzeżenia na temat ówczesnej turystyki, odnosząc się do idei grupowych wyjazdów. O turystyce zorganizowanej nie ma najlepszego zdania, uważając, że niszczy ona twórców i odbiorców sztuki. Ponadto formułuje opinię, że zarówno do Hiszpanii, jak i do każdego innego kraju warto udać się indywidualnie, najlepiej samochodem, aby móc dłużej przebywać w miejscach, które nie są uwzględniane w programach agencji turystycznych oraz uniknąć takich niedogodności, jak zwiedzanie „na czas”, z czym spotkał się w muzeum Prado oraz katedrze w Toledo.

W latach 70. XX w. Serbowie podróżowali najpierw tylko po Serbii, następnie po całej Jugosławii, w końcu zaczęli poznawać świat. Na popularność Hiszpanii jako celu wypraw ówczesnych turystów z Jugosławii zdaniem Popovicia wpłynęły znacznie tańsze niż w jego kraju taksówki, tańsze bilety komunikacji

${ }^{60}$ J. Bartmiński, Język symbolem tożsamości narodowej i świadectwem otwartości, [w:] idem, Stereotypy mieszkaja w języku. Studia etnolingwistyczne, Lublin 2009, s. 25.

${ }^{61}$ P. Kowalski, Odyseje nasze byle jakie. Droga, przestrzeń i podróżowanie w kulturze wspótczesnej, Wrocław 2002, s. 63-64.

62 J. Kolbuszewski, Od „spisków” do przewodników. Przemiany formy i narracji przewodnikowej, [w:] Alegorie, style, tożsamość. W darze Profesor Annie Matuszewskiej, red. M. Łukowska-Schielmann, Gdańsk 1999, s. 54.

63 P. Kowalski, op. cit., s. 64. 
miejskiej oraz niedrogie posiłki w restauracjach. Niższe ceny tych usług sprawiły, że mieszkańcy Jugosławii przyjeżdżali do Hiszpanii na wakacje. Popović, który nieprzychylnie oceniał wyjazdy grupowe, zrewidował swoje nastawienie do tej formy poznawania świata, gdy okazało się, że w czasie wycieczki nawet największy malkontent stawał się uprzejmy i życzliwy.

$$
* * *
$$

Zapiski Popovicia można przyporządkować do kategorii dzienników. Dziennik zaczął kształtować się na przełomie XVIII i XIX w. przede wszystkim we Francji, co pozostawało w związku z formowaniem się nowych koncepcji ludzkiej osobowości, kładących nacisk na indywidualizm i przeżycia osobiste ${ }^{64}$. Dziennik skupiony na życiu wewnętrznym, przedstawiający stany psychiczne i życie codzienne diarysty bywa prowadzony przez wiele lat, niekiedy całe życie, a czasem tylko w latach młodości, w okresie dojrzewania. Znane są też dzienniki krótkie, określone zazwyczaj czynnikami zewnętrznymi, wyznaczającymi zmianę życiową, jak dziennik uwięzienia, choroby, podróży ${ }^{65}$.

Teksty o charakterze dzienników pojawiły się w literaturze serbskiej w okresie romantyzmu. Należą do nich Dziennik (Дневник) z 1836 r., napisany przez bratanicę księcia Miloša Obrenovicia — Ankę Obrenović, Dziennik uczniowski (Ђачки дневник) Dimitrija Maticia z lat 1845-1848, Dziennik (Дневник) Slavka Zlatojevicia z 1849 r., dziennik Milicy Stojadinović Srpkinji Na Fruszkiej Górze 1954 (У Фрушкој гори 1854), dzienniki Jovana Jovanovicia Zmaja z lat 1882 1888, 1889-1890 i 1896-1898 oraz Dziennik (Дневник) Lazy Kosticia z 1909 r. ${ }^{66}$ W okresie modernizmu formę dziennika stosowała Milica Janković w opowiadaniach z cyklu Wyznania (Исповести, 1913), w powieści Zanim nadejdzie szczęście (Пре cpeћe, 1918) i w utworze $W$ czterech ścianach (Међу зидовима, $1932)^{67}$. Z kolei Jelena Dimitrijević włączyła do powieści Nowe (Нове, 1912) dziennik intymny, zaś w książkach Nowy Świat lub rok w Ameryce (Нови Cвет или у Америци годину дана, 1934) i Siedem mórz i trzy oceany. Podróż dookoła świata (Седам мора и три океана. Путем око света, 1940) wykorzystała formę dziennika z podróży ${ }^{68}$.

Trudno zgodzić się z tezą, że spośród wszystkich utworów wchodzących w skład Dzienników z podróży Popovicia charakter dziennika mają tylko notatki związane z pobytem autora w Stanach Zjednoczonych ${ }^{69}$. Współtworząca Dzien-

${ }^{64}$ Stownik terminów literackich, s. 118.

${ }^{65}$ M. Czermińska, O autobiografii i autobiograficzności, [w:] Autobiografia, red. M. Czermińska, Gdańsk 2009, s. 13-14.

${ }^{66}$ M. Koch, ...kiedy dojrzejemy jako kultura... Twórczość pisarek serbskich na początku XX wieku, Wrocław 2007, s. 160-161.

${ }^{67}$ Ibidem, s. 162-182.

${ }^{68}$ Ibidem, s. 182.

69 М. Ђорђевић, оp. cit. 
niki relacja $\mathrm{z}$ Hiszpanii w pełni odpowiada bowiem wymogom stawianym tego rodzaju utworom. Dziennik z reguły składa się z szeregu zapisów dotyczących rozmaitych problemów i tematów. Rozpiętość formalna zapisu jest ogromna: od chaotycznego toku myśli i przeżyć po wywody logiczne i zracjonalizowane. Jedynym obowiązującym porządkiem jest układ chronologiczny zapisów ${ }^{70}$. Połączone datą serie zapisów czy notatek mają określoną strukturę — początek, koniec, ewentualnie wewnętrzny podział tematyczny lub retoryczny ${ }^{71}$. Zapis w dzienniku tworzony jest na bieżąco. Seria zapisów nie musi być codzienna ani regularna; odstęp pomiędzy zapisami może być znaczny, a zapisy mogą być oddalone w czasie ${ }^{72}$.

Hiszpańska relacja serbskiego malarza składa się z dwudziestu jeden zapisków opatrzonych nie tylko datą i godziną, lecz także precyzyjnie określonym miejscem powstania każdego z nich. Podróż na Półwysep Iberyjski rozpoczęła się dla autora o piątej rano w kuchni belgradzkiego mieszkania („, пет сати у кухињи на Студентском тргу у Београду" [s. 143]). Artysta wykorzystywał każdą chwilę, by utrwalać swoje wrażenia i opinie, które powstawały nawet kilka razy dziennie - w samolocie, w barze, w pociągu jadącym z Toledo do Madrytu, w kawiarnianym ogródku, w restauracji, na lotnisku czy w hotelu.

Dziennik niemal zawsze sporządzany jest odręcznie przez samego diarystę, z zachowaniem jego charakteru pisma. Niekiedy zanotowanemu śladowi towarzyszą zasuszone kwiaty, drobne przedmioty, znaki graficzne oraz rysunki ${ }^{73}$. To właśnie rysunki urozmaicają Dzienniki z podróży; stanowią też stały element innych utworów literackich serbskiego malarza, ozdabiają m.in. książkę Zderzenia $i$ harmonie oraz wydany $\mathrm{w}$ formie książkowej wywiad $\mathrm{z}$ autorem ${ }^{74}$.

Dziennik, podobnie jak dzieło sztuki, istnieje w jednym egzemplarzu. Czytając dziennik w formie drukowanej, mamy więc prawo wątpić, czy jest to ten sam tekst, który stworzył autor pod wpływem wydarzeń chwili i towarzyszących mu emocji. Poprawione czy przeredagowane zapiski, zyskując — być może — na wartości literackiej, tracą jednakże autentyczność chwili, w której powstały ${ }^{75}$.

Jovan Popović, syn autora Dzienników, redagując notatki ojca, musiał dokonać selekcji materiału, tak by całość nie została nadmiernie obciążona szczegółami osobistymi ${ }^{76}$. W części dzienników dotyczących podróży do Hiszpanii nie ma wielu zapisów, które mogłyby zostać uznane za zbyt intymne. Do tej kategorii można zaliczyć jedynie wypowiedzi skierowane bezpośrednio do członków najbliższej rodziny. Miodrag Popović dzieli się bowiem swoimi wrażeniami ze zwiedzania Pra-

70 Stownik terminów literackich, s. 118.

${ }^{71} \mathrm{Ph}$. Lejeune, „Drogi zeszycie...”, „,drogi ekranie...”. O dziennikach osobistych, przeł.

A. Karpowicz, M. Rodak, P. Rodak, wybór, wstęp i oprac. P. Rodak, Warszawa 2010, s. 50-51.

72 Ibidem, s. 36-37.

73 Ibidem, s. 37.

${ }^{74}$ М. Глигоријевић, op. cit.

75 Ph. Lejeune, op. cit., s. 37.

76 J. Поповић, Предговор, [w:] М. Поповић, Путописни дневници, Београд 2006, s. 10-11. 
do z żoną — malarką Verą Božičković-Popović (1920-2002), kierując do niej uwagi dotyczące konkretnych obrazów (np. „Вера, изненадиће те три Ботичелијеве слике. Никад ништа слично ниси видела” [s. 151]). Pisarz pragnie także podzielić się z rodziną przeżyciami ze spektaklu corridy. Jednak o szczegółach dotyczących samej walki zamierza poinformować bliskich osobiście, dlatego pomija ten fragment w notatkach sporządzanych „na gorąco” w Hiszpanii, zapowiada natomiast szczegółową relację ustną po powrocie („Ритуал у свих шест убистава [...] ја ћу вам [...], Вера и Јоване, испричати" [s. 156]).

Bodźcem do prowadzenia dziennika może być każdy aspekt aktywności ludzkiej. Popovicia skłaniały do tego przede wszystkim podróże, które dzięki lekturze książek podróżniczych polubił jeszcze w czasach gimnazjalnych ${ }^{77}$. Dziennik pisał już od grudnia 1945 do stycznia 1946 r. Były to zapiski, które powstały najpierw w więzieniu, w miejscowości Beli Manastir, a następnie w areszcie śledczym w Somborze ${ }^{78}$.

Forma i styl zapisków zależą od tego, czy notuje się po to, aby pomóc swojej pamięci, czy też z intencją, by to, co zostało zapisane, zyskało aprobatę ${ }^{79} . \mathrm{Z}$ opinii syna Miodraga Popovića wynika, że twórca nie zamierzał publikować swoich notatek z podróży zagranicznych, nie proponował ich żadnemu wydawnictwu. Jednak odczytując je w gronie przyjaciół ${ }^{80}$, uczynił z nich utwory częściowo znane.

Relacje z podróży rzeczywistej łączą cechy dokumentu (faktografii), biografii i fikcji. Przewaga któregoś z tych aspektów wpływa na kształt utworu, jego kompozycję i rolę, jaką w tekście odgrywa autor, co uwidacznia się zwłaszcza w różnych dziełach opisujących wyprawy do tych samych miejsc, a także przy porównywaniu poszczególnych relacji spisanych $\mathrm{w}$ takiej samej konwencji gatunkowej ${ }^{81}$. W omawianych utworach już na płaszczyźnie konstrukcji tekstu, poprzez utożsamienie narratora $\mathrm{z}$ autorem, obecne jest założenie autobiograficzne — od ujęcia, w którym osobowość i przeżycia autora dominują nad opisywaną rzeczywistością, po ukrywanie się za artystycznym opisem i refleksjami z jednej strony, a faktografią $z$ drugiej ${ }^{82}$. Pisanie o podróżowaniu to pisanie o sobie, o swoim stosunku do świata, o własnej tożsamości skonfrontowanej z tym, co stanowi dla niej wyzwanie ${ }^{83}$.

Dziennik jest przekazem skierowanym do alter ego zagubionego w przyszłości albo skromnym wkładem w zbiorową pamięć $c^{84}$. Dzienniki z podróży, podob-

77 М. Поповић, Како је било у ђачкој дружини «Јавор», пред рат, [w:] М. Глигоријевић, op. cit., s. 17.

78 М. Поповић, Ухапшен и спроведен у батаљонски затвор, [w:] М. Глигоријевић, op. cit., s. 37.

${ }^{79} \mathrm{Ph}$. Lejeune, op. cit., s. 36-37.

${ }^{80}$ Ibidem, s. 38. Zob. М. Ђорђевић, op. cit.

${ }^{81}$ D. Kozicka, Wędrowcy światów prawdziwych. Dwudziestowieczne relacje z podróży, Kraków 2003, s. 21.

82 Ibidem, s. 89.

83 W.J. Burszta, Różnorodność i tożsamość. Antropologia jako kulturowa refleksyjność, Poznań 2004, s. 61.

${ }^{84}$ Ibidem, s. 39. 
nie jak wydane ponad pół wieku wcześniej Zderzenia i harmonie, ukazują kolejną ważną sferę artystycznej działalności malarza i scenarzysty, który dał się poznać jako autor relacji z podróży.

W pochodzących z lat 70. XX w. relacjach z Hiszpanii, które stanowią zapis osobistych wrażeń i przeżyć trojga autorów: Miodraga Kujundžicia (Białe domy i czarne byki), Milki Lučić (Nasz przewodnik Don Kichot) i Miodraga Popovicia (Podróż do Hiszpanii) można wskazać odmienne dominanty tematyczne, chociaż relacje te zawierają wiele punktów wspólnych, jak chociażby doświadczenia charakterystyczne dla wyjazdów stricte turystycznych, trudności z podporządkowaniem się rygorom wycieczki zorganizowanej, zwiedzanie tych samych miast, odwiedzanie tych samych miejsc czy spostrzeżenia dotyczące współczesnych mieszkańców oraz aktualnych problemów kraju.

Na wizerunek wykreowany przez Kujundžicia składają się opisy najważniejszych zabytków z czasów arabskich oraz rozważania dotyczące historii kraju, wypierania muzułmanów z Półwyspu. W ujęciu Milki Lučić dominują odwołania do przeszłości chrześcijańsko-muzułmańskiej, opisy budowli sakralnych oraz reminiscencje malarskie i literackie, przy czym treść przywołanych dzieł literackich wykracza poza racjonalne pojmowanie świata, podkreślając znaczenie wyobraźni ${ }^{85}$. Z kolei tematykę relacji Popovicia zdominowało malarstwo: dzieła z kolekcji Prado i Muzeum Sztuki Współczesnej, zbiory Eskurialu oraz muzeów i kościołów Toledo. W mieście nad Tagiem bohaterem dziennika został bez wątpienia El Greco. Po obejrzeniu prac tego artysty Popović zaczął wszystkie inne obrazy postrzegać jak „wyroby rzemieślnicze” („боље или горе занатске производе", [s. 147]). Pisarz odnosi się w swoich zapiskach zarówno do płócien malarzy hiszpańskich (El Greco, Velázquez, Ribera, Zurbarán, Goya, Dalí, Picasso), jak i twórców obcych (Tycjan, Rubens, Breugel, Bosch, van der Weyden). Wizyty w muzeach dały mu możliwość zrozumienia przeszłości ${ }^{86}$, a spektakle corridy i flamenco pozwoliły dostrzec związek między poszczególnymi elementami kultury i historii hiszpańskiej — dziełami Goi, przejawami zbiorowej ekspresji, wojną domową, rysunkami Picassa i Dalego.

Biorąc pod uwagę pasje i zainteresowania Popovicia, można zauważyć, że w swoim dzienniku wymienia on stosunkowo niewiele dzieł malarskich (Pogrzeb hrabiego Orgaza, Kuźnia Wulkana, Zdjęcie z krzyża), rezygnuje też z ich szczegółowego opisu. Czasem w konkretnym dziele intryguje go jedynie jakiś detal. Jako

${ }^{85}$ Bardziej szczegółowo na temat obrazu Hiszpanii w relacjach Miodraga Kujundžicia i M. Lučić zob. M. Filipek, U zemlji belih kuća i crnih bikova: utisci iz Španije Miodraga Kujundžića, „Serbian Studies Research” 4, 2013, nr 1, s. 51-65; eadem, Milki Lučić wrażenia z podróży do Hiszpanii, [w:] Stowianie w podróży, t. 2. Literatura, red. M. Guštin, N. Wyszogrodzka-Liberadzka, Gdańsk 2016, s. 213-228.

${ }^{86}$ H. Belting, op. cit., s. 86. 
malarz zwraca uwagę na sposób operowania światłem. Zachwyca się m.in. oświetleniem Pogrzebu hrabiego Orgaza, światłem w kompozycjach Goi, słońcem, które rozjaśnia krajobraz okolic pasma górskiego Sierra de Guadarrama. Popović skupia się na swych doznaniach wywołanych oglądaniem serii dzieł poszczególnych twórców (Picasso, Dalí), jednak w dzienniku ich opis jest bardzo zredukowany i sprowadza się zwykle do kilku uwag, dotyczących sposobu nakładania farb, który np. u Velazqueza przypomina „фугу у музици” (s. 155), czy odnoszących się do kompozycji, jak w wypadku obrazu Ribery Męczeństwo świętego Barttomieja.

Mówienie czy pisanie o obrazach zmusza autora wypowiedzi do akcentowania dystansu dzielącego tekst traktujący o obrazie od wizualnej rzeczywistości dzieła ${ }^{87}$. Według Popovicia dzieło plastyczne, które charakteryzuje się ,przedstawianiem czegoś” oraz „sugerowaniem czegoś”, pozostawia widzowi możliwość, aby sam wyjaśnił jego fenomen ${ }^{88}$. Dlatego uwagi Popovicia na temat malarstwa, które w założeniu stanowi główny aspekt opisywanej przez niego rzeczywistości hiszpańskiej, są dość ogólnikowe. Autor Dzienników z podróży, występując w podwójnej roli — widza (obserwatora obrazów) i artysty-malarza (twórcy obrazów), powstrzymuje się od fachowych uwag na temat malarstwa, gdyż pozostawia sobie jako widzowi możliwość indywidualnej interpretacji dzieł i tworzenia nowych sposobów ich odczytywania. Ze względu na wybór prac malarskich z muzeów Madrytu, Toledo i Eskurialu, które autor przedstawił w Dziennikach z podróży, oraz biorąc pod uwagę obecność w tekście własnych rysunków Popovicia, czytelnik staje się gościem w swoistej galerii obrazów, po której oprowadza go serbski artysta, układający własną, subiektywną historię malarstwa ${ }^{89}$.

\section{Bibliografia}

Bartmiński J., Język symbolem tożsamości narodowej i świadectwem otwartości, [w:] idem, Stereotypy mieszkają w języku. Studia etnolingwistyczne, Lublin 2009.

Barton S., Historia Hiszpanii, przeł. A. Mścichowska, M. Mścichowski, Warszawa 2011.

Belting H., Antropologia obrazu. Szkice do nauki o obrazie, przeł. M. Bryl, Kraków 2007.

Бихаљи-Мерин О., Јединство света у визији уметности, Београд 1974.

Botton A. de, Sztuka podróżowania, przeł. H. Pustuła, Warszawa 2010.

Burszta W.J., Różnorodność i tożsamość. Antropologia jako kulturowa refleksyjność, Poznań 2004.

Czermińska M., O autobiografii i autobiograficzności, [w:] Autobiografia, red. M. Czermińska, Gdańsk 2009.

Ђорђевић М., Да ме је Михиз видео... Белешке, иртежи и приче из Мексика, Ирана, са Тајланда, Америке..., http:// www. politika.rs/rubrike/Kultura/t13627.

Filipek M., Milki Lučić wrażenia z podróży do Hiszpanii, [w:] Słowianie w podróży, t. 2. Literatura, red. M. Guštin, N. Wyszogrodzka-Liberadzka, Gdańsk 2016.

${ }^{87}$ H. Holender, Literatura-malarstwo-grafika. Interakcje, funkcje i konkurencja, [w:] Ut pictura poesis, red. M. Skwara, S. Wysłouch, Gdańsk 2006, s. 194.

88 М. Поповић, Једини излаз: исмејати манипулисане ионе којиманипулишу, [w:] М. Глигоријевић, op. cit., s. 91.

89 J. Поповић, Предговор, [w:] idem, Путописни дневници, Београд 2006, s. 8. 
Filipek M., U zemlji belih kuća i crnih bikova: utisci iz Španije Miodraga Kujundžića, „Serbian Studies Research" 4, 2013, nr 1.

Gállego J., „Pogrzeb hrabiego Orgaza” jako portret, [w:] A. Biała, Literatura i malarstwo. Korespondencja sztuk, Warszawa-Bielsko Biała 2010.

Глигоријевић М., Одговор Миће Поповића, Београд 1984.

Hintzen-Bohlen B., Andaluzja. Sztuka i architektura, przeł. H. Hartwig, [b.m.w.] 2008.

Holender H., Literatura - malarstwo - grafika. Interakcje, funkcje i konkurencja, [w:] Ut pictura poesis, red. M. Skwary, S. Wysłouch, Gdańsk 2006.

Јаћимовић С., Путописи српске авангарде, Београд 2005.

Kapuściński R., Ten Inny, Kraków 2006.

Koch M., ...kiedy dojrzejemy jako kultura... Twórczość pisarek serbskich na poczatku XX wieku, Wrocław 2007.

Kolbuszewski J., Od „spisków” do przewodników. Przemiany formy i narracji przewodnikowej, [w:] Alegorie, style, tożsamość. W darze Profesor Annie Matuszewskiej, red. M. Łukowska-Schielmann, Gdańsk 1999.

Kowalski P., Odyseje nasze byle jakie. Droga, przestrzeń i podróżowanie w kulturze współczesnej, Wrocław 2002.

Kozicka D., Wędrowcy światów prawdziwych. Dwudziestowieczne relacje z podróży, Kraków 2003.

Lejeune Ph., „Drogi zeszycie...”, „,drogi ekranie...”. O dziennikach osobistych, przeł. A. Karpowicz, M. Rodak, P. Rodak, wybór, wstęp i oprac. P. Rodak, Warszawa 2010.

Levey M., Od Giotta do Cézanne'a. Zarys historii malarstwa zachodnioeuropejskiego, przeł. M. Bańkowska, S. Bańkowski, Warszawa 1972.

Miłkowski T., Machcewicz P., Historia Hiszpanii, Wrocław 1998.

Ortega y Gasset J., Velázquez i Goya, przeł. R. Kalicki, Warszawa 1993.

Płaszczewska O., Wizja Włoch w polskiej i francuskiej literaturze okresu romantyzmu (1800-1850), Kraków 2003.

Поповић Ј., Предговор, [w:] М. Поповић, Путописни дневници, Београд 2006.

Поповић М., Дочао је сочијалистички човек једне димензије, [w:] М. Глигоријевић, Одговор Миће Поповића, Београд 1984.

Поповић М., Једини излаз: исмејатиманипулисане ионе којиманипулишу, [w:] М. Глигоријевић, Одговор Миће Поповића, Београд 1984.

Podemski K., Socjologia podróży, Poznań 2004.

Поповић М., Како је било у ђачкој дружини «Јавор», пред рат, [w:] М. Глигоријевић, Одговор Миће Поповића, Београд 1984.

Поповић М., Судари и хармоније, Нови Сад 1954.

Поповић М., Треба ћутати и стрепети, [w:] М. Глигоријевић, Одговор Миће Поповића, Београд 1984.

Prens H.O., Golobof H.M., Istorija hispanoameričke književnosti, sa španskog prevela M. Josimčević, Beograd 1982.

Słownik terminów literackich, red. M. Głowiński et al., Wrocław 2000.

Urry J., Spojrzenie turysty, przeł. A. Szulżycka, Warszawa 2007.

Wieczorkiewicz A., Apetyt turysty. O doświadczaniu świata w podróży, Kraków 2008.

Winczakiewicz J., Andaluzja i Kastylia. Antologia poezji hiszpańskiej XX wieku, Londyn 1963. 


\section{Spain in Miodrag Popović's travel diaries}

\section{Summary}

In addition to well-known works about Spain, written by prominent writers and diplomats of the Kingdom of Yugoslavia (Zorić, Dučić, Petrović, Dimitrijević, Andrić, Crnjanski), Serbian literature is full of less famous fiction that has complemented the country's image through Serbian readers since the 70's of 20th century to the present. One of them is a literary work Put u Španiju (from the travel book, entitled Putopisni dnevnici, by Miodrag Popović). The writer describes impressions from a trip to Spain and other countries. Visiting the most famous museums of Madrid (Prado, Museum of Modern Art), monastery of El Escorial and churches and museums of Toledo, Popović draws his attention to the paintings and creates subjective, alternative gallery of global paintings.

Keywords: Miodrag Popović, Spain, diary, imagination, museums, paintings, travel diaries.

\section{Шпанија у путописној прози Миодрага Поповића}

\section{Резиме}

Осим познатих дела о Шпанији, чији су аутори били истакнути писци и дипломати из Краљњвинњ Србије и Краљњвине Југославије (Зорић, Дучић, Петровић, Димитријевић, Андрић, Црњански) у српској књижевности постоје и мање потнати текстови који допуњују слику ове земље од 70.-тих година XX века до данашњих времена. Један од њих је Put u Španiju, из књиге Putopisni dnevnici, Миодрага Поповића који у овој књизи описује своје утиске из Шпаније и других земаља. Посећујући најпознатије музеје Мадрида (Прадо, Музеј савремене уметности), манастир Ескоријал, цркве и музеје Толеда концентрише се пре сцега на сликама, и на тај начин ствара своју субјективну галерију светског сликарства.

Кључне речи: Миодраг Поповић, Шпанија, дневник, уобразиља, музеји, слике. 